Analisis Perbandingan Biaya Dan Waktu Saluran Drainase Batu Kali Dengan Beton Readymix Dan

Beton Pracetak Pada Ruas Jalan Boyolangu - Campurdarat Kabupaten Tulungagung Saddam Al Akbar Al Satria, Kustamar, Lies K. Wulandari

\title{
ANALISIS PERBANDINGAN BIAYA DAN WAKTU SALURAN DRAINASE BATU KALI DENGAN BETON READYMIX DAN BETON PRACETAK PADA RUAS JALAN BOYOLANGU - CAMPURDARAT KABUPATEN TULUNGAGUNG
}

\author{
Saddam Al Akbar Al Satria ${ }^{1}$, Kustamar ${ }^{2}$, Lies K. Wulandari ${ }^{3}$ \\ 1Degree Program of Civil Engineering Department, National Institut of Technology, Malang, Indonesia-65140 \\ 2,3Post Graduate Program of Civil Engineering Department, National Institut of Technology, Malang, Indonesia-65140
}

\begin{abstract}
ABSTRAK
Ruas Jalan Boyolangu - Campurdarat merupakan jalur utama menuju ke destinasi kawasan wisata di pesisir selatan kabupaten tulungagung, jalur ini saat musim hujan sering terjadi banjir dikarenakan saluran drainase tidak mampu menampung air hujan sehingga mengakibatkan air meluap dan menggenangi jalan. Selain itu kendaraan yang melintas memperlambat lajunya yang menimbulkan kepadatan bahkan kemacetan lalu lintas, yang harus segera ditangani dengan normalisasi saluran atau pembuatan saluran drainase baru. Metode alternatif jenis material pembuatan saluran drainase dibutuhkan untuk mempersingkat waktu pelaksanaan pekerjaan dan meminimalkan jumlah tenaga kerja. Salah satu jenis material pembuatan saluran drainase adalah dari beton readymix dan beton pracetak U-ditch. Perbedaan jenis material pembuat saluran ini dengan konvensional adalah pembuatanya dilakukan secara pabrikasi, yang pelaksanaanya di lokasi pekerjaan tinggal dipasang dan tidak membutuhkan waktu yang lama, sehingga tidak menimbulkan kemacetan lalu lintas yang berkepanjangan.

Berdasarkan hasil perhitungan saluran drainase dengan panjang 7.750 meter dengan jumlah tenaga kerja 200 orang/hari didapatkan biaya saluran drainase dengan batu kali Rp. 17.242.200.000,- dengan waktu pelaksanaan 393,78 hari, saluran drainase dengan beton readymix Rp. 20.896.325.000,- dengan waktu pelaksanaan 305,72 hari, saluran drainase dengan precast u-ditch Rp. 41.546.200.000,- dengan waktu pelaksanaan 164,6 hari,
\end{abstract}

Kata Kunci : Perbandingan Biaya dan Waktu, Saluran Drainase Jalan.

\section{PENDAHULUAN}

Pembangunan Jalur Lintas Selatan (JLS) yang melintasi pantai di kawasan pesisir selatan Kabupaten Tulungagung membuka tempat wisata baru seperti Pantai Gemah yang ramai dikunjungi wisatawan lokal maupun luar kota (www.pu.go.id, 28 Agustus 2017), hal ini menunjukkan prasarana transportasi sangat berperan penting dalam mendorong peningkatan perekonomian dalam sektor pariwisata.

Ruas Jalan Boyolangu - Campurdarat merupakan jalur utama yang dilintasi kendaraan pribadi maupun bus-bus besar untuk menuju ke destinasi kawasan wisata di pesisir selatan, selain itu industri batu alam untuk bahan baku keramik maupun batu hias marmer yang mulai menunjukkan peningkatan dalam sepuluh tahun terakhir ini mengakibatkan ruas jalan ini juga dilewati truk-truk besar pengangkut batu alam yang menuju pabrik di sekitar surabaya.

Dari lokasi atau letak geografis yang berada di dataran rendah Kabupaten Tulungagung saat musim hujan sering terjadi banjir pada waktu curah hujan yang tinggi, aliran yang deras mengakibatkan saluran drainase tidak mampu menampung air hujan sehingga mengakibatkan air meluap dan menggenangi jalan. Selain itu kendaraan yang melintas memperlambat lajunya sehingga menimbulkan kepadatan bahkan kemacetan lalu lintas, maka masalah tersebut harus segera ditangani dengan normalisasi saluran atau pembuatan saluran drainase baru.

Pada proses pembangunan saluran drainase, mayoritas perencanaan pada Dinas Pekerjaan Umum masih menggunakan material konvensional yang dilakukan secara langsung pada lokasi proyek, namun terdapat kekurangan antara lain membutuhkan waktu pengerjaan yang lama, dan peletakan material pekerjaan konstruksi memakan badan jalan sehingga menyebabkan kemacetan lalu lintas dalam jangka waktu yang panjang (www.surabaya.tribunnews.com, 05 Juni 2018). 
Analisis Perbandingan Biaya Dan Waktu Saluran Drainase Batu Kali Dengan Beton Readymix Dan Beton Pracetak Pada Ruas Jalan Boyolangu - Campurdarat Kabupaten Tulungagung Saddam Al Akbar Al Satria, Kustamar, Lies K. Wulandari

Metode perbandingan jenis material pembuatan saluran drainase dibutuhkan untuk mempersingkat waktu pelaksanaan pekerjaan dan meminimalkan jumlah tenaga kerja. Salah satu jenis material pembuatan saluran drainase adalah dari beton readymix dan beton pracetak U-ditch.

Perbedaan jenis material pembuat saluran ini dengan konvensional adalah pembuatanya dilakukan secara pabrikasi, yang pelaksanaanya di lokasi pekerjaan tinggal dipasang dan tidak membutuhkan waktu yang lama, sehingga tidak menimbulkan kemacetan lalu lintas yang berkepanjangan.

\section{LANDASAN TEORI}

\section{Drainase}

Drainase yang berasal dari bahasa inggris drainage yang mempunyai arti mengalirkan, membuang, atau mengalihkan air. Dalam bidang teknik sipil, drainase secara umum dapat didefinisikan sebagai suatu tindakan teknis untuk mengurangi kelebihan air, baik yang berasal dari hujan, rembesan maupun kelebihan air irigasi di suatu kawasan/lahan, sehingga fungsi kawasan tidak terganggu. Drainase juga diartikan sebagai usaha untuk mengontrol kualitas air tanah dalam kaitannya dengan salinitas. Jadi, drainase menyangkut tidak hanya air permukaan tapi juga air tanah. (Suripin : 2004)

Analisa Hidrologi

Analisa hidrologi dilakukan berdasarkan data curah hujan harian yang ada dari stasiun - stasiun penakar curah hujan. Analisa ini dilakukan untuk mengetahui debit banjir rencana, yang nantinya akan digunakan untuk merencanakan dimensi saluran. berikut:

Perhitungan curah hujan daerah maksimum menggunakan Metode rata-rata, dengan rumus sebagai

$$
R r=\frac{R_{1}+R_{2}+\ldots+R_{n} .}{n}
$$

Keterangan Rumus :

$\mathrm{Rr} \quad=$ Curah hujan daerah rata - rata $(\mathrm{mm})$.

$\mathrm{Rn} \quad=$ Data curah hujan dari stasiun pengamatan.

$\mathrm{n} \quad=$ Jumlah stasiun pengamatan.

\section{Uji Konsistensi}

$$
\text { = Jumlah stasiun pengamatan. }
$$

Pengujian konsistensi dilakukan dengan Metode Curve Massa Ganda, dengan rumus sebagai berikut :

$$
f k=\frac{\beta}{\alpha}
$$

Keterangan Rumus :

$\mathrm{fk}=$ Faktor Koreksi

$\beta=$ Kemiringan kurve setelah patahan.

a = Kemiringan kurve sebelum patahan.

\section{Distribusi Probabilitas}

Penentuan jenis distribusi probabilitas yang sesuai dengan data dilakukan dengan mencocokkan parameter data tersebut dengan syarat masing-masing jenis distribusi seperti pada tabel berikut :

Tabel 1. Penentuan Jenis Distribusi

\begin{tabular}{|c|c|c|}
\hline No & Distribusi & Persyaratan \\
\hline 1 & Gumbel & $\begin{array}{c}\mathrm{C}_{\mathrm{s}}=1,14 \\
\mathrm{C}_{\mathrm{k}}=5,4\end{array}$ \\
\hline 2 & Normal & $\begin{array}{c}\mathrm{C}_{\mathrm{s}}=0 \\
\mathrm{C}_{\mathrm{k}}=4\end{array}$ \\
\hline 3 & Log Normal & $\mathrm{C}_{\mathrm{s}}=\mathrm{C}_{\mathrm{v}}{ }^{3}+3 \mathrm{C}_{\mathrm{v}}$ \\
& & $\mathrm{C}_{\mathrm{k}}=\mathrm{C}_{\mathrm{v}}{ }^{6}+6 \mathrm{C}_{\mathrm{v}}{ }^{6}+15 \mathrm{C}_{\mathrm{v}}{ }^{4}+3$ \\
\hline 4 & Log Pearson Type III & Selain dari nilai diatas \\
\hline
\end{tabular}

Sumber : T, Bambang, 2008

\section{Perhitungan Intensitas Hujan Metode Mononobe}


Analisis Perbandingan Biaya Dan Waktu Saluran Drainase Batu Kali Dengan Beton Readymix Dan Beton Pracetak Pada Ruas Jalan Boyolangu - Campurdarat Kabupaten Tulungagung Saddam Al Akbar Al Satria, Kustamar, Lies K. Wulandari

Jika data hujan jangka pendek tidak tersedia, dan yang tersedia adalah data hujan harian maka persamaan regresinya dapat diturunkan dengan Metode Mononobe, dengan rumus (Made, 2011) sebagai berikut :

$$
\begin{aligned}
& I=\frac{X_{24}}{24} \times \frac{24^{2 / 3}}{t} \\
& \text { Keterangan } \\
& \begin{array}{ll}
\mathrm{I} \text { Rumus : } \\
\mathrm{X}_{24} \quad=\text { Intensitas hujan rencana (mm). } \\
\mathrm{t} \quad=\text { Durasi hujan atau waktu konsentrasi (jam) }
\end{array}
\end{aligned}
$$

\section{Perhitungan Debit Banjir Rencana Metode Rasional}

Perhitungan Debit Banjir Rencana Metode Rasional, dapat dilakukan dengan rumus (Made, 2011) sebagai berikut :

$\mathrm{Q}=0,278 \times \mathrm{C} \times \mathrm{I} \times$ AKeterangan Rumus :

$\mathrm{Q}=$ Debit puncak limpasan permukaan ( $\left.\mathrm{m}^{3} / \mathrm{det}\right)$.

$\mathrm{C}=$ Angka pengaliran (tanpa dimensi).

$A=$ Luas daerah pengaliran $\left(\mathrm{Km}^{2}\right)$.

$\mathrm{I}=$ Intensitas curah hujan ( $\mathrm{mm} / \mathrm{jam})$.

Kapasitas Saluran

Perhitungan kapasitas saluran drainase melihat bentuk penampang saluran dengan menggunakan rumus Manning's sebagai berikut :

$$
\begin{aligned}
& Q=\frac{1}{n} \cdot R^{2 / 3} \cdot I^{1 / 2} \cdot A \\
& \text { Dimana: } \\
& \begin{aligned}
\mathrm{Q} & =\text { debit dalam m/det } \\
\mathrm{A} & =\text { luas penampang basah } \\
\mathrm{R} & =\text { jari-jari hidraulis } \\
\mathrm{I} & =\text { kemiringan saluran } \\
\mathrm{n} & =\text { koefisien kekasaran }
\end{aligned}
\end{aligned}
$$

\section{Waktu Pelaksanaan Pekerjaan}

Perencanaan Waktu dan jumlah tenaga kerja dapat dihitung dengan rumus sebagai berikut :

$$
\begin{aligned}
& \mathrm{N} \quad=\frac{k \times V}{T} \\
& \text { Dimana : } \\
& \mathrm{N}=\text { Jumlah Tenaga Kerja } \\
& \mathrm{k}=\text { Koefisien Tenaga Kerja dalam Analisa Harga Satuan } \\
& \mathrm{V}=\text { Kuantitas Pekerjaan } \\
& \mathrm{T}=\text { Lama Pekerjaan }
\end{aligned}
$$

\section{METODOLOGI PENELITIAN}

Metode yang digunakan adalah :

a) Library Study. Metode yang dilakukan dengan membaca literatur atau mempelajari berbagai buku terutama tentang teori-teori yang berhubungan dengan permasalahan dan sebagai pembanding teori dan praktek.

b) Field Research. Metode yang dilakukan dengan mendatangi tempat penelitian secara langsung ke lapangan. Dalam hal ini teknik yang digunakan adalah: teknik dokumentasi dan teknik observasi.

\section{HASIL DAN PEMBAHASAN}


Analisis Perbandingan Biaya Dan Waktu Saluran Drainase Batu Kali Dengan Beton Readymix Dan Beton Pracetak Pada Ruas Jalan Boyolangu - Campurdarat Kabupaten Tulungagung Saddam Al Akbar Al Satria, Kustamar, Lies K. Wulandari

\section{Curah Hujan Daerah Maksimum}

Penentuan curah hujan daerah maksimum menggunakan Metode Aljabar, dimana tinggi curah hujan rata - rata diperoleh dengan tinggi curah hujan pada stasiun pengamatan dibagi dengan banyaknya stasiun pengamatan.

Tabel 2. Perhitungan Curah Hujan Rerata

\begin{tabular}{|c|c|c|c|c|c|}
\hline \multirow{2}{*}{ No } & \multirow{2}{*}{ Tahun } & \multicolumn{2}{|c|}{ Curah Hujan Max Stasiun (mm) } & \multirow{2}{*}{ Rerata } \\
\cline { 3 - 5 } & & Bandung & Besuki & Campurdarat & \\
\cline { 3 - 5 } & $\mathbf{R 1}$ & $\mathbf{R 2}$ & $\mathbf{R 3}$ & \multirow{2}{*}{ R1+R2+R3)/3 } \\
\hline 1 & $\mathbf{2 0 1 0}$ & 158 & 320 & 123 & 200,33 \\
\hline 2 & $\mathbf{2 0 1 1}$ & 86 & 105 & 69 & 86,67 \\
\hline 3 & $\mathbf{2 0 1 2}$ & 67 & 108 & 61 & 78,67 \\
\hline 4 & $\mathbf{2 0 1 3}$ & 88 & 89 & 84 & 87,00 \\
\hline 5 & $\mathbf{2 0 1 4}$ & 61 & 114 & 58 & 77,67 \\
\hline 6 & $\mathbf{2 0 1 5}$ & 61 & 139 & 54 & 84,67 \\
\hline 7 & $\mathbf{2 0 1 6}$ & 95 & 151 & 108 & 118,00 \\
\hline 8 & $\mathbf{2 0 1 7}$ & 51 & 66 & 91 & 69,33 \\
\hline 9 & $\mathbf{2 0 1 8}$ & 118 & 132 & 91 & 113,67 \\
\hline 10 & $\mathbf{2 0 1 9}$ & 106 & 96 & 132 & 111,33 \\
\hline
\end{tabular}

Dari hasil perhitungan curah hujan daerah maksimum dengan metode Aljabar di tiga stasiun pengamatan diperoleh $\bar{X}=102,73 \mathrm{~mm} /$ tahun

\section{Uji Konsistensi}

Uji Konsistensi data dimaksudkan untuk mengetahui kebenaran data lapangan yang dipengaruhi oleh spesifikasi alat penakar hujan berubah, tempat alat ukur dipindah, dan perubahan lingkungan di sekitar alat penakar hujan.

Jika dari hasil pengujian ternyata data adalah konsisten artinya tidak terjadi perubahan lingkungan dan cara penakaran, sebaliknya jika ternyata data tidak konsisten artinya terjadi perubahan lingkungan dan cara penakaran.

Tabel 3. Perhitungan Uji Konsistensi Pada Stasiun Bandung

\begin{tabular}{|c|c|c|c|c|c|c|c|c|}
\hline \multicolumn{9}{|c|}{$\begin{array}{l}\text { Uji Konsistensi Stasiun Bandung } \\
\text { Metode Curve Massa Ganda } \\
\end{array}$} \\
\hline \multirow{2}{*}{ No } & \multirow{2}{*}{ Tahun } & \multicolumn{4}{|c|}{ Curah Hujan Max (mm) } & \multirow{2}{*}{$\begin{array}{c}\text { Rerata Stasiun (mm) } \\
\text { Besuki \& Campurdarat }\end{array}$} & \multicolumn{2}{|c|}{ Komulatif Stasiun (mm) } \\
\hline & & \begin{tabular}{|l|} 
Bandung \\
\end{tabular} & Besuki & Campurdarat & Rata-rata & & Bandung & Referensi \\
\hline 1 & 2010 & 158 & 320 & 123 & 200,33 & 221,5 & 158,0 & 221,5 \\
\hline 2 & 2011 & 86 & 105 & 69 & 86,67 & 87,0 & 244,0 & 308,5 \\
\hline 3 & 2012 & 67 & 108 & 61 & 78,67 & 84,5 & 311,0 & 393,0 \\
\hline 4 & 2013 & 88 & 89 & 84 & 87,00 & 86,5 & 399,0 & 479,5 \\
\hline 5 & 2014 & 61 & 114 & 58 & 77,67 & 86,0 & 460,0 & 565,5 \\
\hline 6 & 2015 & 61 & 139 & 54 & 84,67 & 96,5 & 521,0 & 662,0 \\
\hline 7 & 2016 & 95 & 151 & 108 & 118,00 & 129,5 & 616,0 & 791,5 \\
\hline 8 & 2017 & 51 & 66 & 91 & 69,33 & 78,5 & 667,0 & 870,0 \\
\hline 9 & 2018 & 118 & 132 & 91 & 113,67 & 111,5 & 785,0 & 981,5 \\
\hline 10 & 2019 & 106 & 96 & 132 & 111,33 & 114,0 & 891,0 & 1095,5 \\
\hline & & & & Total & 1027,33 & & & \\
\hline & & & & Rerata & 102,73 & & & \\
\hline
\end{tabular}


Analisis Perbandingan Biaya Dan Waktu Saluran Drainase Batu Kali Dengan Beton Readymix Dan Beton Pracetak Pada Ruas Jalan Boyolangu - Campurdarat Kabupaten Tulungagung Saddam Al Akbar Al Satria, Kustamar, Lies K. Wulandari

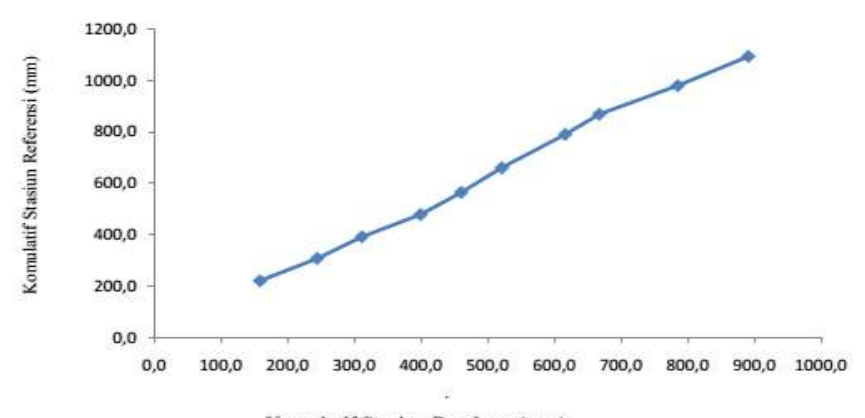

Gambar 1. Uji Konsistensi Pada Stasiun Bandung

Berdasarkan grafik analisa Curve Massa Ganda, apabila terjadi kemiringan yang besar / patahan maka perlu dilakukan koreksi (mengalikan atau membagi data sebelum atau sesudah perubahan / patahan).

Berdasarkan Grafik diatas, komulatif Stasiun terlihat tidak terjadi perubahan kemiringan yang berarti, artinya data Stasiun konsisten.

\section{Uji Homogenitas}

Uji Homogenitas dimaksudkan untuk mengetahui apakah seri data yang terkumpul dari 3 stasiun pengukur yang berada di dalam suatu daerah pengaliran atau salah satu berada di luar daerah pengaliran yang bersangkutan berasal dari populasi yang sama atau bukan.

Tabel 4. Perhitungan Uji Homogenitas Curah Hujan

\begin{tabular}{|c|c|c|c|c|c|c|c|c|c|c|}
\hline \multicolumn{5}{|c|}{ Stasiun Bandung } & \multicolumn{3}{|c|}{ Stasiun Besuki } & \multicolumn{3}{|c|}{ Stasiun Campurdarat } \\
\hline No & Tahun & $\mathrm{X}_{\mathrm{li}}$ & $X_{1 i}-X r t$ & $\left(X_{1 i}-X r t\right)^{2}$ & $\mathrm{X}_{2 \mathrm{i}}$ & $\mathrm{X}_{2 \mathrm{i}}-\mathrm{Xrt}$ & $\left(\mathrm{X}_{2 \mathrm{i}}-\mathrm{Xrt}\right)^{2}$ & $\mathrm{X}_{3 \mathrm{i}}$ & $\mathrm{X}_{3 \mathrm{i}}-\mathrm{Xrt}$ & $\left(X_{3 i}-X r t\right)^{2}$ \\
\hline 1 & 2010 & 158 & 68,9 & 4747,21 & 320 & 188,0 & 35344,00 & 123 & 35,9 & 1288,81 \\
\hline 2 & 2011 & 86 & $-3,1$ & 9,61 & 105 & $-27,0$ & 729,00 & 69 & $-18,1$ & 327,61 \\
\hline 3 & 2012 & 67 & $-22,1$ & 488,41 & 108 & $-24,0$ & 576,00 & 61 & $-26,1$ & 681,21 \\
\hline 4 & 2013 & 88 & $-1,1$ & 1,21 & 89 & $-43,0$ & 1849,00 & 84 & $-3,1$ & 9,61 \\
\hline 5 & 2014 & 61 & $-28,1$ & 789,61 & 114 & $-18,0$ & 324,00 & 58 & $-29,1$ & 846,81 \\
\hline 6 & 2015 & 61 & $-28,1$ & 789,61 & 139 & 7,0 & 49,00 & 54 & $-33,1$ & 1095,61 \\
\hline 7 & 2016 & 95 & 5,9 & 34,81 & 151 & 19,0 & 361,00 & 108 & 20,9 & 436,81 \\
\hline 8 & 2017 & 51 & $-38,1$ & 1451,61 & 66 & $-66,0$ & 4356,00 & 91 & 3,9 & 15,21 \\
\hline 9 & 2018 & 118 & 28,9 & 835,21 & 132 & 0,0 & 0,00 & 91 & 3,9 & 15,21 \\
\hline \multirow[t]{3}{*}{10} & 2019 & 106 & 16,9 & 285,61 & 96 & $-36,0$ & 1296,00 & 132 & 44,9 & 2016,01 \\
\hline & $\Sigma$ & 891 & & 9432,90 & 1320 & & 44884,00 & 871 & & 6732,90 \\
\hline & Xrt & 89,10 & & & 132,00 & & & 87,10 & & \\
\hline
\end{tabular}

Dari Tabel nilai t kritis, dapat diketahui untuk $d k=27$ dan derajat kepercayaan $a=5 \%$ atau $t_{0,05}$ diperoleh nilai tabel $\boldsymbol{t}=\mathbf{1 , 7 0 3 .}$

Karena (t hasil perhitungan) -4,735 $<1,703$ ( $t$ tabel) maka dapat disimpulkan bahwa data hujan dari stasiun Bandung, Besuki, dan Campurdarat adalah homogen atau berasal dari satu populasi.

\section{Uji Distribusi Probabilitas}

Uji distribusi probabilitas dimaksudkan untuk mengetahui apakah persamaan distribusi probabilitas yang dipilih dapat mewakili distribusi statistik data yang dianalisis.

Dalam Uji distribusi probabilitas ini terdapat 2 metode pengujian distribusi probabilitas, yaitu Metode Chi Kuadrat dan Metode Smirnov Kolmogorov.

\section{Uji Distribusi Probabilitas Metode Chi Kuadrat}

Perhitungan Distribusi Probabilitas Uji Chi Kuadrat sebagai berikut :

1) Menentukan jumlah kelas.

Jumlah data $(\mathrm{n})=10$

$\mathrm{K}=1+3.22 \log \mathrm{n}$

$\mathrm{K}=1+3.22 \log 10$ 
Analisis Perbandingan Biaya Dan Waktu Saluran Drainase Batu Kali Dengan Beton Readymix Dan Beton Pracetak Pada Ruas Jalan Boyolangu - Campurdarat Kabupaten Tulungagung Saddam Al Akbar Al Satria, Kustamar, Lies K. Wulandari

$\mathrm{K}=4,3 \approx 5$ Kelas

2) Menentukan derajat kebebasan (Dk) dan $X^{2} \mathrm{cr}$.

Parameter $(\mathrm{p}) \quad=2$

Derajat kebebasan $(D k)=K-(p+1)=5-(2+1)=2$

Nilai $\mathrm{X}^{2} \mathrm{Cr}$ dengan jumlah data $(n)=10, a=5 \%, D k=2$, Adalah 5,991

3) Menentukan interval kelas distribusi

Kelas distribusi $=1 / 5 \times 100 \%=20 \%$

Interval distribusi adalah $=20 \% ; 40 \% ; 60 \% ; 80 \%$

- $P(x)=20 \%$ diperoleh $\mathrm{T}=1 / \mathrm{Px}=1 / 0,20=5$

- $P(x)=40 \%$ diperoleh $T=1 / P x=1 / 0,40=2,5$

- $P(x)=60 \%$ diperoleh $T=1 / P x=1 / 0,60=1,67$

- $P(x)=80 \%$ diperoleh $T=1 / P x=1 / 0,80=1,25$

4) Menentukan interval kelas

a. Distribusi Probabilitas Gumbel

Jumlah data $(n)=10$

$\mathrm{Yn}=0,4952$

Sn $=0,9497$

$Y t=-\operatorname{Ln}\left(-\operatorname{Ln} \frac{T-1}{T}\right)$

$K=\frac{Y t-Y n}{S n}=\frac{Y t-0,4952}{0,9497}$

Sehingga :

$\begin{array}{llllll}\mathbf{T}= & 5,00 & \mathbf{Y t}= & 1,500 & \mathbf{K}= & \mathbf{1 , 0 5 8} \\ \mathbf{T}= & 2,50 & \mathbf{Y t}= & 0,672 & \mathbf{K}= & \mathbf{0 , 1 8 6} \\ \mathbf{T}= & 1,67 & \mathbf{Y t}= & 0,087 & \mathbf{K}= & \mathbf{- 0 , 4 2 9} \\ \mathbf{T}= & 1,25 & \mathbf{Y t}= & -0,476 & \mathbf{K}= & \mathbf{- 1 , 0 2 3}\end{array}$

Nilai $X=102,733$

Nilai $S=38,163$

Maka interval kelas

$\mathrm{X}_{\mathrm{T}}=102,733+38,163+\mathrm{K}$

$\begin{array}{lllll}\mathbf{X} & \mathbf{5 , 0 0} & = & 143,108 & \mathrm{~mm} \\ \mathbf{X} \mathbf{2 , 5 0} & = & 109,827 & \mathrm{~mm} \\ \mathbf{X} \mathbf{1 , 6 7} & = & 86,347 & \mathrm{~mm} \\ \mathbf{X} \mathbf{1 , 2 5} & =63,711 & \mathrm{~mm}\end{array}$

Tabel 5. Perhitungan Chi Kuadrat Distribusi Gumbel

\begin{tabular}{|c|cc|c|c|c|c|}
\hline No & \multicolumn{2}{|c|}{ Interval } & Ei & Oi & (Oi-Ei)^2 & (Oi-Ei)^2/Ei \\
\hline 1 & $>143,108$ & & 2,00 & 1,00 & 1,00 & 0,50 \\
\hline 2 & $143,108-109,827$ & 2,00 & 3,00 & 1,00 & 0,50 \\
\hline 3 & $109,827-86,347$ & 2,00 & 2,00 & 0,00 & 0,00 \\
\hline 4 & $86,347-63,711$ & 2,00 & 4,00 & 4,00 & 2,00 \\
\hline 5 & 63,711 & 2,00 & 0,00 & 4,00 & 2,00 \\
\hline & Jumlah & $\mathbf{1 0}$ & $\mathbf{1 0}$ & & $\mathbf{5 , 0}$ \\
\hline
\end{tabular}

b. Distribusi Probabilitas Log Normal

Nilai $\mathrm{K}_{\mathrm{T}}$ berdasarkan nilai $\mathrm{T}$ dari didapat :
$\mathbf{T}=5,00$
$\mathbf{K t}=\mathbf{0 , 8 4}$
$\mathbf{T}=2,50$
$\mathbf{K t}=\quad 0,25$
$\mathbf{T}=1,67$
$\mathbf{K} \mathbf{t}=-0,25$ 
Analisis Perbandingan Biaya Dan Waktu Saluran Drainase Batu Kali Dengan Beton Readymix Dan

Beton Pracetak Pada Ruas Jalan Boyolangu - Campurdarat Kabupaten Tulungagung Saddam Al Akbar Al Satria, Kustamar, Lies K. Wulandari

$\mathbf{T}=1,25$

$\mathbf{K} \mathbf{t}=-0,84$

Nilai $\log X=1,9908$

Nilai SLogX $=0,134$

Tabel 6. Perhitungan Chi Kuadrat Distribusi Log Normal

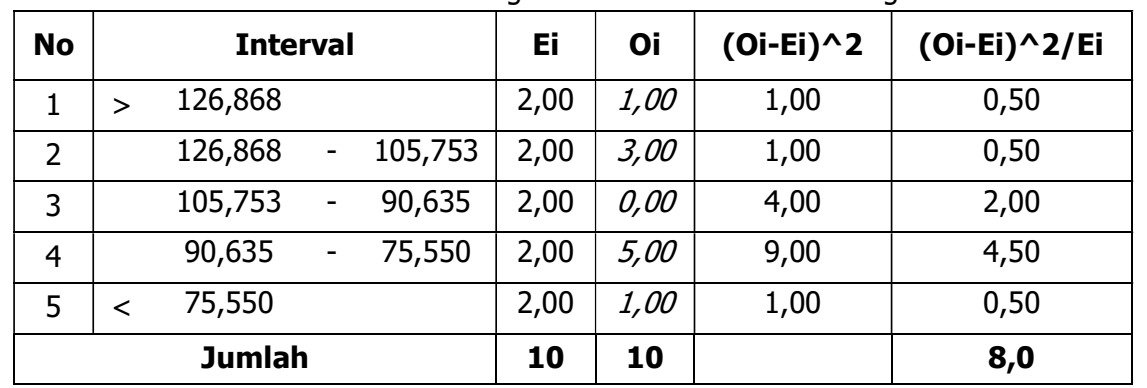

c. Distribusi Probabilitas Log Pearson Type III

Nilai $\mathrm{K}_{\mathrm{T}}$ dihitung berdasarkan nilai $\mathrm{Cs}$ atau $\mathrm{G}=1,459$ dan nilai $\mathrm{T}$ untuk berbagai periode ulang adalah :

$\begin{array}{llll}\mathrm{T}= & 5,00 & \mathrm{Kt}= & 0,69 \\ \mathrm{~T}= & 2,50 & \mathrm{Kt}= & -0,24 \\ \mathrm{~T}= & 1,67 & \mathrm{Kt}= & -0,5 \\ \mathrm{~T}= & 1,25 & \mathrm{Kt}= & -0,83\end{array}$

Tabel 7. Perhitungan Chi Kuadrat Distribusi Log Pearson Type III

\begin{tabular}{|c|c|c|c|c|c|c|c|c|}
\hline No & \multicolumn{4}{|c|}{ Interval } & $\mathbf{E i}$ & Oi & $(\mathrm{Oi}-\underline{\underline{\mathrm{Fi}}})^{\wedge} 2$ & $(\mathrm{Oi}-\underline{\underline{\mathrm{Fi}}})^{\wedge} 2 / \mathrm{Ei}$ \\
\hline 1 & $>$ & 121,130 & & & 2,00 & 1,00 & 1,00 & 0,50 \\
\hline 2 & & 121,130 & - & 90,915 & 2,00 & 3,00 & 1,00 & 0,50 \\
\hline 3 & & 90,915 & - & 83,907 & 2,00 & 3,00 & 1,00 & 0,50 \\
\hline 4 & & 83,907 & - & 75,784 & 2,00 & 2,00 & 0,00 & 0,00 \\
\hline 5 & $<$ & 75,784 & & & 2,00 & 1,00 & 1,00 & 0,50 \\
\hline & & Jumla & & & 10 & 10 & & 2,0 \\
\hline
\end{tabular}

5) Rekapitulasi Nilai $X^{2}$ dan $X^{2} \mathrm{cr}$ untuk 3 Distribusi

Tabel 8. Rekapitulasi Nilai $X^{2}$ dan $X^{2} \mathrm{cr}$

\begin{tabular}{|l|c|c|c|}
\hline \multicolumn{1}{|c|}{ Distribusi Probabilitas } & X2 Hitung & $\mathbf{X 2 C r}$ & Keterangan \\
\hline Gumbel & 5,0 & 5,991 & Diterima \\
\hline Log Normal & 8,0 & 5,991 & Tidak Diterima \\
\hline Log Pearson Type III & 2,0 & 5,991 & Diterima \\
\hline
\end{tabular}

Berdasarkan tabel perhitungan diatas, jika $\mathrm{X}^{2}<\mathrm{X}_{\mathrm{Cr}}$ Tabel. Maka distribusi dapat diterima, Sehingga dipakai distribusi yang terkecil adalah Log Pearson TypeIII.

Uji Distribusi Probabilitas Metode Smirnov Kolmogorov

Tabel 9. Perhitungan Uji Smirnov Kolmogorov 
Analisis Perbandingan Biaya Dan Waktu Saluran Drainase Batu Kali Dengan Beton Readymix Dan Beton Pracetak Pada Ruas Jalan Boyolangu - Campurdarat Kabupaten Tulungagung Saddam Al Akbar Al Satria, Kustamar, Lies K. Wulandari

\begin{tabular}{|c|c|c|c|c|c|c|c|c|}
\hline \multirow{2}{*}{ XI (mm) } & \multirow{2}{*}{ m } & \multirow{2}{*}{$\begin{array}{l}P=m / \\
(N+1)\end{array}$} & \multicolumn{2}{|c|}{ Log Normal } & \multicolumn{2}{|c|}{ Log Pearson III } & \multicolumn{2}{|c|}{ Gumbel } \\
\hline & & & $\mathbf{P}^{\prime}(\mathrm{Xi})$ & $\Delta \mathbf{P}$ & $\mathbf{P}^{\prime}(\mathrm{Xi})$ & $\Delta \mathbf{P}$ & $\mathbf{P}^{\prime}(\mathrm{Xi})$ & $\Delta \mathbf{P}$ \\
\hline 200,333 & 1 & 0,091 & 0,010 & $-0,081$ & 0,032 & $-0,059$ & 0,021 & $-0,070$ \\
\hline 118,000 & 2 & 0,182 & 0,273 & 0,091 & 0,219 & 0,037 & 0,285 & 0,104 \\
\hline 113,667 & 3 & 0,273 & 0,314 & 0,042 & 0,249 & $-0,024$ & 0,322 & 0,049 \\
\hline 111,333 & 4 & 0,364 & 0,338 & $-0,025$ & 0,267 & $-0,097$ & 0,343 & $-0,020$ \\
\hline 87,000 & 5 & 0,455 & 0,649 & 0,194 & 0,572 & 0,118 & 0,614 & 0,160 \\
\hline 86,667 & 6 & 0,545 & 0,654 & 0,108 & 0,579 & 0,033 & 0,618 & 0,073 \\
\hline 84,667 & 7 & 0,636 & 0,681 & 0,045 & 0,616 & $-0,020$ & 0,643 & 0,007 \\
\hline 78,667 & 8 & 0,727 & 0,761 & 0,034 & 0,740 & 0,013 & 0,717 & $-0,011$ \\
\hline 77,667 & 9 & 0,818 & 0,774 & $-0,045$ & 0,762 & $-0,056$ & 0,728 & $-0,090$ \\
\hline 69,333 & 10 & 0,909 & 0,868 & $-0,041$ & 0,937 & 0,028 & 0,822 & $-0,087$ \\
\hline \multicolumn{2}{|l|}{$\Delta \mathrm{P} \max =$} & & & 0,194 & & 0,118 & & 0,160 \\
\hline \multicolumn{2}{|c|}{$\Delta \mathrm{P}$ kritis (Tabel) $=$} & 0,41 & & & & & & \\
\hline \multicolumn{2}{|c|}{$\Delta P$ hit $<\Delta P$ Tabel } & & \multicolumn{2}{|c|}{ Diterima } & \multicolumn{2}{|c|}{ Diterima } & \multicolumn{2}{|c|}{ Diterima } \\
\hline
\end{tabular}

Dari Tabel perhitungan Uji Smirnov Kolmogorov diatas dengan derajat kepencengan $a=5 \%$ maka diperoleh nilai $\mathrm{a}=0,41$, Maka bila nilai $\Delta \mathrm{P}<\Delta \mathrm{P}$ Kritis perhitungan dapat diterima, sehingga diambil nilai $(\Delta \mathrm{P})$ terkecil yaitu Distribusi Probabilitas Log Person Type III.

\section{Perhitungan Rencana Anggaran Biaya}

Biaya pembuatan saluran drainase pada ruas jalan Boyolangu - Campurdarat dapat dihitung dengan analisa harga satuan pekerjaan sebagai berikut :

Tabel 10. Harga Upah Pekerja Bahan dan Peralatan Kab. Tulungagung 2020

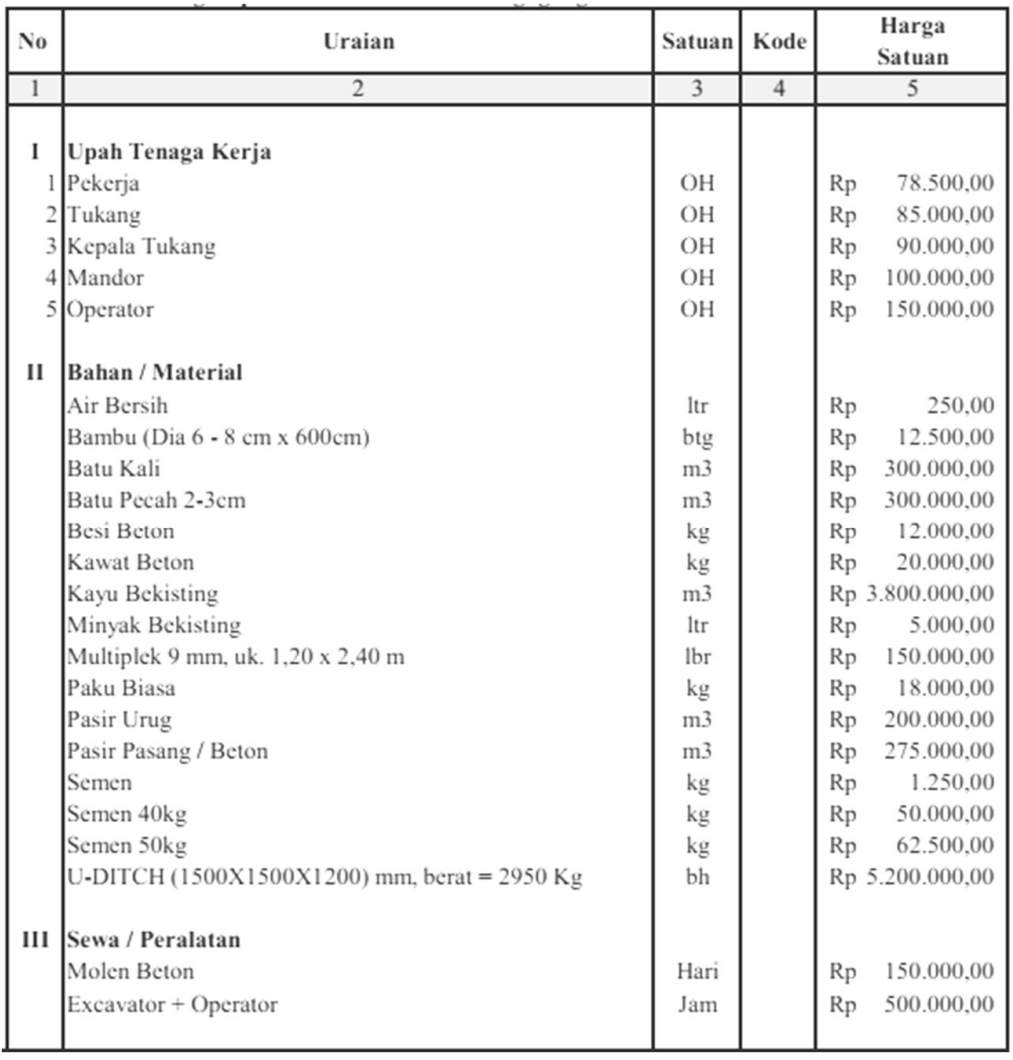


Analisis Perbandingan Biaya Dan Waktu Saluran Drainase Batu Kali Dengan Beton Readymix Dan Beton Pracetak Pada Ruas Jalan Boyolangu - Campurdarat Kabupaten Tulungagung Saddam Al Akbar Al Satria, Kustamar, Lies K. Wulandari

Sumber : Dinas Pu Kab Tulungagung 2020

\section{Perhitungan Harga Per $\mathbf{m}$ ' Saluran dengan batu kali}

Berdasarkan perhitungan volume dan analisa harga satuan pekerjaan diatas maka dapat dihitung :

Tabel 11.Harga per $\mathrm{m}^{\prime}$ Pasangan Batu Kali

\begin{tabular}{|c|c|c|c|c|c|c|c|}
\hline No & Item Pekerjaan & Vol & Sat & \multicolumn{2}{|c|}{ Harga Satuan } & \multicolumn{2}{|c|}{ Jumlah Harga } \\
\hline 1 & 2 & 3 & 4 & & 5 & \multicolumn{2}{|c|}{6} \\
\hline$I$ & Pekerjaan Saluran Batu Kali & & & & & & \\
\hline 1 & - Galian tanah & 3,780 & $\mathrm{~m} 3$ & $\mathrm{Rp}$ & $65.711,25$ & $\mathrm{Rp}$ & $248.388,53$ \\
\hline 2 & - Urugan Pasir & 0,105 & $\mathrm{~m} 3$ & $\mathrm{Rp}$ & $302.940,00$ & $\mathrm{Rp}$ & $31.808,70$ \\
\hline 3 & - Pas Batu & 1,530 & $\mathrm{~m} 3$ & $\mathrm{Rp}$ & $1.049 .345,00$ & $\mathrm{Rp}$ & $1.605 .497,85$ \\
\hline 4 & - Pek Siaran & 4,500 & $\mathrm{~m} 2$ & $\mathrm{Rp}$ & $57.062,50$ & $\mathrm{Rp}$ & $256.781,25$ \\
\hline 5 & - Pek Plesteran & 1,100 & $\mathrm{~m} 2$ & $\mathrm{Rp}$ & $74.848,40$ & $\mathrm{Rp}$ & $82.333,24$ \\
\hline & & & & & Jumlah & $R p$ & $2.224 .809,57$ \\
\hline & & & & & Dibulatkan & $R p$ & $2.224 .800,00$ \\
\hline
\end{tabular}

\section{Perhitungan Harga Per $\mathbf{m}$ ' Saluran dengan beton readymix}

Berdasarkan perhitungan volume dan analisa harga satuan pekerjaan diatas maka dapat dihitung :

Tabel 12. Harga per $m^{\prime}$ Pasangan Beton Readymix

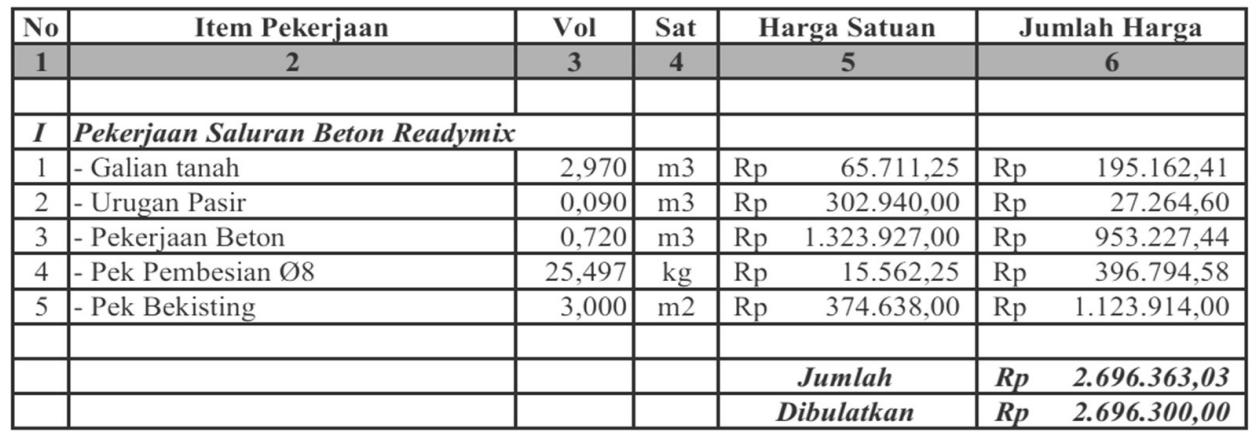

\section{Perhitungan Harga Per m' Saluran dengan precast u-ditch}

Berdasarkan perhitungan volume dan analisa harga satuan pekerjaan diatas maka dapat dihitung :

Tabel 13. AHSP Pekerjaan Pasang U-DItch

\begin{tabular}{|c|c|c|c|c|c|c|c|}
\hline No & Item Pekerjaan & Vol & Sat & \multicolumn{2}{|c|}{ Harga Satuan } & \multicolumn{2}{|c|}{ Jumlah Harga } \\
\hline 1 & 2 & 3 & 4 & & 5 & \multicolumn{2}{|r|}{6} \\
\hline$I$ & \multicolumn{2}{|l|}{ Pekerjaan Saluran Precast U-Ditch } & & & & & \\
\hline 1 & - Galian tanah & 2,819 & $\mathrm{~m} 3$ & $\mathrm{Rp}$ & $65.711,25$ & $\mathrm{Rp}$ & $185.226,87$ \\
\hline 2 & - Urugan Pasir & 0,087 & $\mathrm{~m} 3$ & $\mathrm{Rp}$ & $302.940,00$ & $\mathrm{Rp}$ & $26.355,78$ \\
\hline 3 & - Pekerjaan Pemasangan U-Ditch & 1,000 & $\mathrm{~m}^{\prime}$ & $\mathrm{Rp}$ & $5.149 .234,75$ & $\mathrm{Rp}$ & $5.149 .234,75$ \\
\hline & & & & & & & \\
\hline & & & & & & & \\
\hline & & & & & & & \\
\hline & & & & & Jumlah & $R p$ & $5.360 .817,40$ \\
\hline & & & & & ibulatkan & $R p$ & $5.360 .800,00$ \\
\hline
\end{tabular}

\section{Rekapitulasi Rencana Anggaran Biaya}

Pada tabel berikut ini adalah hasil perhitungan biaya keseluruhan pekerjaan antara saluran batu kali, saluran beton readymix dan saluran precast u-ditch :

Tabel 14. Rekapitulasi Harga Pekerjaan Saluran 
Analisis Perbandingan Biaya Dan Waktu Saluran Drainase Batu Kali Dengan Beton Readymix Dan Beton Pracetak Pada Ruas Jalan Boyolangu - Campurdarat Kabupaten Tulungagung Saddam Al Akbar Al Satria, Kustamar, Lies K. Wulandari

\begin{tabular}{|c|c|c|c|c|c|}
\hline No & Item Pekerjaan & Vol & Sat & Harga Satuan & Jumlah Harga \\
\hline $\mathbf{1}$ & $\mathbf{2}$ & $\mathbf{3}$ & $\mathbf{4}$ & $\mathbf{5}$ & $\mathbf{6}$ \\
\hline & & & & & \\
\hline 1 & Pekerjaan Saluran Batu Kali & $7.750,00$ & $\mathrm{~m}^{\prime}$ & $\mathrm{Rp} 2.224 .800,00$ & $\mathrm{Rp} 17.242 .200 .000,00$ \\
\hline 2 & Pekerjaan Saluran Beton Readymix & $7.750,00$ & $\mathrm{~m}^{\prime}$ & $\mathrm{Rp} 2.696 .300,00$ & $\mathrm{Rp} 20.896 .325 .000,00$ \\
\hline 3 & Pekerjaan Saluran Precast U-Ditch & $7.750,00$ & $\mathrm{~m}$ & $\mathrm{Rp} 5.360 .800,00$ & $\mathrm{Rp} 41.546 .200 .000,00$ \\
\hline & & & & & \\
\hline & & & & & \\
\hline
\end{tabular}

\section{Perhitungan Jumlah Tenaga dan Waktu Pelaksanaan}

Perhitungan jumlah tenaga dan waktu pelaksanaan pekerjaan pembuatan saluran drainase sebagai berikut :

- Galian tanah :

Koefisien pekerja $=0,6750$

Koefisien mandor $=0,0675$

Volume $\quad=29.295 \mathrm{m3}$

$$
=0,675+0,0675=0,7425
$$

Mandays $\quad=29.295 \times 0,7425=21.751,54$

Waktu pekerjaan $=21.751,54$ / 200orang perhari $=108,758$ Hari

\section{Pekerjaan Saluran Pasangan Batu Kali}

Waktu pelaksanaan pekerjaan dengan tenga kerja 200 orang /hari

Tabel 15. Rekapitulasi Waktu Pekerjaan Batu Kali

\begin{tabular}{|c|c|c|c|c|c|c|}
\hline No & Uraian Pekerjaan & Volume & Satuan & Koefisien & \multicolumn{2}{|c|}{ Manday's } \\
\hline 1 & 2 & 3 & 4 & 5 & \multicolumn{2}{|c|}{$6=(3 \times 5)$} \\
\hline & & & & & & \\
\hline$\frac{1}{2}$ & \begin{tabular}{|l} 
- Urugan Pasir \\
\end{tabular} & 813,75 & $\mathrm{~m} 3$ & 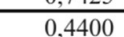 & 358,05 & Orang \\
\hline 3 & - Pas Batu & $11.857,50$ & $\mathrm{~m} 3$ & 2,8800 & $34.149,60$ & Orang \\
\hline 4 & - Pek Siaran & $34.875,00$ & $\mathrm{~m} 2$ & 0,4950 & $17.263,13$ & Orang \\
\hline 5 & - Pek Plesteran & $8.525,00$ & $\mathrm{~m} 2$ & 0,6140 & $5.234,35$ & Orang \\
\hline \multirow{2}{*}{\multicolumn{5}{|c|}{ Jumlah Mandays }} & & \\
\hline & & & & & 78.757 & Orang \\
\hline \multicolumn{5}{|c|}{ Jumlah Rata-Rata Tenaga Kerja Yang Diperlukan Per Hari } & 200 & orang/hari \\
\hline \multicolumn{5}{|c|}{ Jumlah Hari Kerja } & 394 & hari \\
\hline & & & & & 13,13 & bulan \\
\hline
\end{tabular}

\section{Pekerjaan Saluran Beton Readymix}

Waktu pelaksanaan pekerjaan dengan tenaga kerja 200 orang /hari

Tabel 16. Rekapitulasi Waktu Pekerjaan Beton Readymix

\begin{tabular}{|c|c|c|c|c|c|c|}
\hline No & Uraian Pekerjaan & Volume & Satuan & Koefisien & \multicolumn{2}{|c|}{ Manday's } \\
\hline 1 & 2 & 3 & 4 & 5 & \multicolumn{2}{|c|}{$6=(3 \times 5)$} \\
\hline 1 & -Galian tanah & 2301750 & $m 3$ & 07425 & 1709040 & Orang \\
\hline 2 & - Urugan Pasir & 697,50 & $\mathrm{~m} 3$ & 0,4400 & 306,90 & Orang \\
\hline 3 & - Pekerjaan Beton & $5.580,00$ & $\mathrm{~m} 3$ & 2,9050 & $16.209,90$ & Orang \\
\hline 4 & - Pek Pembesian $\varnothing 8$ & 197.603 .69 & $\mathrm{~kg}$ & 0,0151 & 2.983 .82 & Orang \\
\hline 5 & - Pek Bekisting & $23.250,00$ & $\mathrm{~m} 2$ & 1,0560 & $24.552,00$ & Orang \\
\hline & & & & & & \\
\hline \multicolumn{5}{|c|}{ Jumlah Mandays } & 61.143 & Orang \\
\hline \multicolumn{5}{|c|}{ Jumlah Rata-Rata Tenaga Kerja Yang Diperlukan Per Hari } & 200 & orang/hari \\
\hline \multicolumn{5}{|c|}{ Jumlah Hari Kerja } & 306 & hari \\
\hline & & & & & 10,19 & bulan \\
\hline
\end{tabular}


Analisis Perbandingan Biaya Dan Waktu Saluran Drainase Batu Kali Dengan Beton Readymix Dan Beton Pracetak Pada Ruas Jalan Boyolangu - Campurdarat Kabupaten Tulungagung Saddam Al Akbar Al Satria, Kustamar, Lies K. Wulandari

Pekerjaan Saluran Precast U-Ditch

Waktu pelaksanaan pekerjaan dengan tenaga kerja 200 orang /hari

Tabel 17. Rekapitulasi Waktu Pekerjaan Precast

\begin{tabular}{|c|c|c|c|c|c|c|}
\hline No & Uraian Pekerjaan & Volume & Satuan & Koefisien & \multicolumn{2}{|c|}{ Manday's } \\
\hline 1 & 2 & 3 & 4 & 5 & \multicolumn{2}{|c|}{$6=(3 \times 5)$} \\
\hline & & & & & & \\
\hline 1 & - Galian tanah & $21.845,70$ & $\mathrm{~m} 3$ & 0,7425 & $16.220,43$ & Orang \\
\hline 2 & - Urugan Pasir & 674,25 & $\mathrm{~m} 3$ & 0,4400 & 296,67 & Orang \\
\hline 3 & - Pekerjaan Pemasangan U-Ditch & $7.750,00$ & $\mathrm{~m}^{\prime}$ & 2,1166 & $16.403,65$ & Orang \\
\hline & & & & & & \\
\hline & & & & & & \\
\hline \multicolumn{5}{|c|}{ Jumlah Mandays } & 32.921 & Orang \\
\hline \multicolumn{5}{|c|}{ Jumlah Rata-Rata Tenaga Kerja Yang Diperlukan Per Hari } & 200 & orang/hari \\
\hline \multicolumn{5}{|c|}{ Jumlah Hari Kerja } & 165 & hari \\
\hline & & & & & 5,49 & bulan \\
\hline
\end{tabular}

\section{Rekapitulasi Total Biaya dan Waktu}

Rekapitulasi perhitungan waktu dan biaya pelaksanaan berbagai jenis material pembuatan saluran sebagai berikut :

Tabel 18. Rekapitulasi Total Biaya dan Waktu

\begin{tabular}{|c|c|c|c|c|c|}
\hline No & Item Pekerjaan & Jumlah Harga & $\begin{array}{c}\text { Tenaga } \\
\text { Kerja Per } \\
\text { Hari }\end{array}$ & $\begin{array}{c}\text { Total Hari } \\
\text { Kerja }\end{array}$ & $\begin{array}{l}\text { Total } \\
\text { Bulan }\end{array}$ \\
\hline 1 & 2 & 3 & 4 & 5 & $\overline{6}$ \\
\hline & & & & & \\
\hline 1 & Pekerjaan Saluran Batu Kali & $\begin{array}{ll}\text { Rp } & 17.242 .200 .000 \\
\end{array}$ & 200 & 393,78 & 13,13 \\
\hline 2 & Pekerjaan Saluran Beton Readymix & Rp 20.896 .325 .000 & 200 & 305,72 & 10,19 \\
\hline 3 & Pekerjaan Saluran Precast U-Ditch & Rp $\quad 41.546 .200 .000$ & 200 & 164,60 & 5,49 \\
\hline
\end{tabular}

\section{KESIMPULAN DAN SARAN}

Kesimpulan

Berdasarkan hasil perhitungan dari penelitian ini dapat diambil kesimpulan sebagai berikut:

1. Pekerjaan saluran drainase dengan batu kali didapatkan biaya Rp. 17.242.200.000,- dengan jangka waktu yaitu $\mathbf{3 9 3 , 7 8}$ hari.

2. Pekerjaan saluran drainase dengan beton readymix didapatkan biaya Rp. 20.896.325.000,- dengan jangka waktu yaitu $\mathbf{3 0 5 , 7 2}$ hari.

3. Pekerjaan saluran drainase dengan precast u-ditch didapatkan biaya Rp. 41.546.200.000,- dengan jangka waktu yaitu 164,60 hari.

\section{Saran}

Berdasarkan kesimpulan di atas, saran yang bisa diberikan adalah:

1. Untuk peneliti selanjutnya, dapat melakukan penambahan jenis bahan / material terbaru seperti lining beton pracetak dan lain sebagainya, sehingga dapat diperoleh alternatif bahan pembuat saluran yang lebih ekonomis namun dengan waktu pelaksanaan yang relatif cepat.

2. Dari hasil perhitungan saluran sepanjang $7.750 \mathrm{~m}$ biaya yang diperlukan lebih dari 10 milyar dengan waktu pelaksanaan lebih dari 6 bulan, maka dapat disarankan saluran dikerjakan per segmen atau lokasi-lokasi yang terdampak genangan / banjir paling kritis terlebih dahulu, mengingat keterbatasan anggaran pada Dinas Pekerjaan Umum Kabupaten Tulungagung,

3. Apabila pekerjaan tidak dilakukan secara sekaligus tapi per segmen, maka dapat dipilih kombinasi jenis bahan pembuatan saluran sehingga tidak hanya terpaku pada satu bahan / material saja, namun keputusan pemilihan bahan saluran tetap pada Dinas Pekerjaan Umum Kabupaten Tulungagung,

\section{DAFTAR PUSTAKA}

Asdak, 1995, Hidrologi dan Pengelolaan Daerah Aliran Sungai, Gadjah Mada University Press, Yogyakarta. 
Analisis Perbandingan Biaya Dan Waktu Saluran Drainase Batu Kali Dengan Beton Readymix Dan Beton Pracetak Pada Ruas Jalan Boyolangu - Campurdarat Kabupaten Tulungagung Saddam Al Akbar Al Satria, Kustamar, Lies K. Wulandari

Badan Standardisasi Nasional, 1994, SNI 03-3424-1994 tentang Tatacara Perencanaan Drainase Permukaan Jalan. BSN, Jakarta.

Chow VT, 1989, Hidrolika Saluran Terbuka, Erlangga, Jakarta.

Dinas Perumahan Permukiman dan Sumber Daya Air, 2020, Data Curah Hujan Tahun 2009 - 2019 Kabupaten Tulungagung, Tidak diterbitkan, Pemerintah Kabupaten, Tulungagung.

Erfiandy Benta, 2018, Analisa Perbandingan Biaya dan Waktu Saluran irigasi Batu Kali Dengan Saluran Irigasi Beton, Tidak diterbitkan, Fakultas Teknik Sipil dan Perencanaan Universitas Islam Indonesia, Yogyakarta.

Ervianto Wulfram I, 2006, Eksplorasi Teknologi dalam Proyek Konstruksi Beton Pracetak \& Bekisting, Penerbit Andi, Yogyakarta.

Hasmar Halim, 2011, Drainasi Terapan, Cetakan Pertama, UII Press, Yogyakarta.

Kamiana Made, 2011, Teknik Perhitungan Debit Rencana Bangunan Air, Graha Ilmu, Yogyakarta.

Kementerian Pekerjaan Umum dan Perumahan, 2017, Jalan Lintas Selatan Ditargetkan Selesai Tahun 2021, https://www.pu.go.id/berita/view/11408/ jalan-lintas-selatan-ditargetkan-selesai-tahun-2021 (diakses tanggal 15 Pebruari 2020).

Soemarto CD, 1987, Hidrologi Teknik. Usaha Nasional, Surabaya.

Sri Harto, 1993, Analisis Hidrologi, Gramedia Pustaka Utama, Jakarta.

Sunggono, 1995, Buku Teknik Sipil, Nova, Bandung.

Suripin, 2004, Sistem Drainase Perkotaan Yang Berkelanjutan. Andi Offset, Yogyakarta.

Triatmodjo Bambang, 2008, Hidrologi Terapan, Beta Offset, Yogyakarta.

Tribunnews, 2018, Tumpukan Material Proyek Ganggu Arus Lalu Lintas di Sejumlah Titik Kota Blitar, https://surabaya.tribunnews.com/2018/06/05 /tumpukan-material-proyek-ganggu-arus-lalu-lintas-disejumlah-titik-kota-blitar (diakses tanggal 15 Pebruari 2020) 